\title{
Changes on physiological parameters of tambaqui (Colossoma macropomum) fed with diets supplemented with Amazonian fruit Camu camu (Myrciaria dubia)
}

\author{
P. H. R. Aride ${ }^{a *}$, A. M. Oliveira ${ }^{b}$, R. B. Batista ${ }^{b}$, M. S. Ferreira ${ }^{b}$, J. Pantoja-Lima ${ }^{c}$, \\ D. S. Ladislau , P. D. S. Castro ${ }^{d}$ and A. T. Oliveira \\ anstituto Federal de Educação, Ciência e Tecnologia do Espírito Santo - IFES, Rua Augusto Costa de Oliveira, 670, \\ CEP 29285-000, Piúma, ES, Brazil \\ bInstituto Nacional de Pesquisas da Amazônia - INPA, Av. André Araújo, 2936, CEP 69067-375, Petrópolis, RJ, Brazil \\ 'Instituto Federal de Educação, Ciência e Tecnologia do Amazonas - IFAM, Av. Onça Pintada, 1302, Galo da Serra, \\ CEP 69057-000, Presidente Figueiredo, AM, Brazil \\ dUniversidade Federal do Amazonas - UFAM, Av. General Rodrigo Otávio Jordão Ramos, 3000, Campus Universitário, \\ CEP 69077-000, Manaus, AM, Brazil \\ 'Instituto Federal de Educação, Ciência e Tecnologia do Amazonas - IFAM, Av. Sete de Setembro, 1975, Centro, \\ CEP 69020-120, Manaus, AM, Brazil \\ *e-mail: aride@ifam.edu.br
}

Received: September 18, 2016 - Accepted: November 30, 2016 - Distributed: May 31, 2018

(With 4 figures)

\begin{abstract}
The physiological responses of juvenile tambaqui (Colossoma macropomum) fed commercial feed supplemented with different concentrations of camu camu (Myrciaria dubia) were evaluated. The design was completely randomized, with treatments arranged in a factorial design with three proportions of camu camu $(15 \%, 30 \%$ and $45 \%)$ and a control treatment (100\% commercial diet), with four replicates per treatment. A total of 96 tambaqui specimens were used, with a mean initial weight of $11.69 \pm 2.68 \mathrm{~g}$ and a mean length of $7.06 \pm 0.44 \mathrm{~cm}$. After 30 days, hematological parameters, metabolic variables, growth and fish swimming performance were evaluated. The different proportions of camu camu in the diet did not cause significant changes to the tambaqui's hematological parameters during the feeding period, except for hemoglobin $(\mathrm{Hb})$ concentration and mean corpuscular hemoglobin concentration (MCHC) after the 30th day, and hematocrit $(\mathrm{Ht})$ after the swimming stress test, which increased significantly $(\mathrm{p}<0.05)$. The significant increases in metabolic variables, such as cortisol, glucose, proteins and triglycerides, and in hematologic variables after the Ucrit test reflect, respectively, biochemical adaptations for maintenance of the energy mobilization process and a regulatory necessity in tissue oxygen demand during intense exercise. Fish fed $15 \%$ and $30 \%$ camu camu gained the most weight and achieved the best swimming performance, respectively. The results for camu camu concentrations above $30 \%$ suggest a saturation of its intrinsic properties in the diet at this level and a loss of nutrients from the commercial feed replaced by the fruit, reducing productive performance and nutritional assimilation.
\end{abstract}

Keywords: Amazon, Colossoma macropomum, Myrciaria dubia, hematology, ascorbic acid.

\section{Alterações em parâmetros fisiológicos de tambaqui (Colossoma macropomum) alimentados com dietas suplementadas com fruta amazônica camu camu (Myrciaria dubia)}

\section{Resumo}

As respostas fisiológicas de juvenis de tambaqui (Colossoma macropomum) alimentados com ração comercial suplementada com diferentes concentrações de camu camu (Myrciaria dubia) foram avaliados. As amostras analisadas foram inteiramente casualizadas, com os tratamentos arranjados em esquema fatorial com três proporções de camu camu $(15 \%, 30 \%$ e $45 \%$ ) e um tratamento controle (ração comercial 100\%), com quatro repetições por tratamento. Um total de 96 amostras de tambaqui foram utilizadas, com um peso médio inicial de 11,69 2,68 g e um comprimento médio de 7,06 0 0,44 cm. Após 30 dias, foram avaliados os parâmetros hematológicos, variáveis metabólicas, crescimento e desempenho natatório de peixes. As diferentes proporções de camu camu na dieta não causou alterações significativas nos parâmetros hematológicos dos tambaquis durante o período de alimentação, com exceção de hemoglobina (Hb) e concentração de hemoglobina corpuscular média (CHCM), após o 30 dia, e hematócrito (Ht), após o teste de natação 
de estresse, que aumentou de forma significativa $(\mathrm{p}<0,05)$. Os aumentos significativos nas variáveis metabólicas, como o cortisol, glicose, proteínas e triglicerídeos, e nas variáveis hematológicas após o teste Ucrit reflete, respectivamente, adaptações bioquímicas para a manutenção do processo de mobilização de energia e uma necessidade de regulamentação na demanda de oxigênio nos tecidos durante o exercício intenso. Os peixes alimentados com $15 \%$ e $30 \%$ de camu camu obtiveram mais peso e melhor desempenho natatório, respectivamente. Os resultados para as concentrações camu camu superiores a 30\% indicam uma saturação das suas propriedades intrínsecas na dieta, a este nível e uma perda de nutrientes a partir da ração comercial substituído pelo fruto, reduzindo o desempenho produtivo e assimilação nutricional.

Palavras-chave: Amazônia, Colossoma macropomum, Myrciaria dubia, hematologia, ácido ascórbico.

\section{Introduction}

The camu camu (Myrciaria dubia) is a native fruit of the Amazon, found in the basin's flood plains and lakes. It has been described as a partial component of the natural diet of aquatic organisms in these areas, especially certain species of fish (Villachica, 1996; Gressler et al., 2006). Currently, camu camu fruit is used for human consumption as a food supplement (Chirinos et al., 2010; Fracassetti et al., 2013) and for medicinal purposes, given its high nutritional value, antioxidant and anti-inflammatory properties, and the highest vitamin $\mathrm{C}$ content among tropical plant species, 3000-6000 mg ascorbic acid per $100 \mathrm{~g}$ pulp (Moraes et al., 1994; Leslie, 1998).

According to Yuyama and Siqueira (1999), the distribution of camu camu seeds in floodplain forests of the Amazon region is achieved through the currents of water courses and endozoochorous dispersal. The tambaqui (Colossoma macropomum) is one of the organisms most responsible for this dispersal route. This fish is omnivorous with zooplantophagous tendencies when young and is frugivorous as an adult (Freeman, 1995), although some authors consider it uniquely fruit-eating (Soares et al., 1986; Eckmann, 1987; Saint-Paul, 1991).

The tambaqui (C. macropomum) is the largest characiform found in the Amazon Basin (Goulding, 1980), where it is widely distributed (Araujo-Lima and Goulding, 1998). This species has great potential for aquaculture due to its husbandry and management qualities, such as good feed conversion, acceptance of artificial food, resistance to long periods of hypoxia and excellent meat quality (Saint-Paul, 1991; Melard et al., 1993; Graef, 1995; Aride et al., 2007). These factors have contributed to it becoming the main species cultivated in northern Brazil (Val et al., 2000; Aride et al., 2016).

Inefficient control of commercial exploitation and illegal fishing of tambaqui have caused a significant reduction in catch in the natural environment (Val et al., 2000), resulting in a greater reliance on stocks cultivated in captivity. As a result, better understanding of the feeding biology of the fish and methods for increasing its availability in the market and maximizing its production form part of a sustainable management strategy for this resource.

This study used biometric, hematological and biochemical variables to determine the physiological effects of feed supplemented with camu camu on C. macropomum. This plant species was evaluated in terms of its potential to be used as a raw material in the breeding of captive fish and thereby in the future to reduce feed costs in the aquaculture in the Amazon Region.

\section{Material and Methods}

\subsection{Ethics statement}

All experimental and animal care procedure was realized before the Brazilian law of Animal Care Committee established in 2009 year. The project ALTALI was approved by National Council for Scientific and Technological Development (CNPq - 554009/2006-4). MS-222 was used as the anesthetic.

\subsection{Origin and culture of experimental animals}

Specimens of juvenile C. macropomum were purchased from the fish farming station of Santo Antônio Farm (Manaus/Amazonas) and were transported to the laboratory (National Institute of Amazonian Research), where they were acclimatized. They then underwent a 15-day adaptation process in 500-L tanks with aeration and constant water renewal. During this period, the experimental animals were fed commercial feed containing $36 \%$ crude protein ad libitum.

The camu camu fruit was kept frozen at $-20{ }^{\circ} \mathrm{C}$ until the day of feed preparation. For the preparation of the test diets, naturally thawed camu camu fruit, milled and seeded, was added in the proportions $15 \%, 30 \%$ and $45 \%$ to the control diet (commercial feed with $36 \%$ crude protein). All feeds were then repelletized, dried in an oven at $55^{\circ} \mathrm{C}$ for 12 hours and stored at $-20^{\circ} \mathrm{C}$. The bromatological values of the fruit and control feed are shown in Table 1.

Table 1. Centesimal compositions of fruit and the test and control feeds used in the experimental design.

\begin{tabular}{lcccccc}
\hline \multicolumn{1}{c}{ Pulp/ Feed } & Moisture (\%) & CP (\%) & EE (\%) & CF (\%) & MM (\%) & NNE (\%) \\
\hline camu camu (in natura) & 11.1 & 3.9 & 7.2 & 20.4 & 1.9 & 55.5 \\
Control & 13.0 & 36.0 & 8.0 & 7.0 & 14.0 & 22.0 \\
15\% camu camu & 13.7 & 37.5 & 5.5 & 5.7 & 9.1 & 28.5 \\
30\% camu camu & 14.0 & 37.3 & 5.5 & 5.4 & 8.8 & 29.0 \\
$45 \%$ camu camu & 14.1 & 37.9 & 5.6 & 5.9 & 8.6 & 27.9 \\
\hline
\end{tabular}

CP: crude protein; EE: ether extract; CF: crude fiber; MM: mineral matter; NNE: non-nitrogenous extract. 
The experiment was conducted using a completely randomized design, where the specimens were distributed into sixteen 60-L PVC tanks (15\%, 30\%, 45\% camu camu and a control group). As reference values, the initial biometrics of all fish and blood samples were taken by puncturing the caudal vein using previously heparinized syringes. The mean initial weight and length were $14.6 \mathrm{~g}$ and $7.5 \mathrm{~cm}$, respectively. Each treatment had six replicates with $\mathrm{N}=10$ (10 fish per tank), totaling 60 fish per treatment. The tanks were maintained with constant aeration, and water was renewed every two days.

The fish were acclimatized in this system for one week and then subjected to the treatments, test feed and control, twice per day ( 9 am and 4 pm), ad libitum. After 15 days of treatment, their biometric values were measured, and blood samples were collected following the procedure described above. For blood samples, two fish per tank was collected to puncturing the caudal vein.

After 30 days of feeding, two fish were randomly collected from each experimental unit and was subjected to a swimming stress test (swimming tunnel). To blood samples collect, fishes was anesthetized with MS-222 (Tricaine methanesulfonate). Final biometry was then performed, and a blood sample taken.

The temperature, dissolved oxygen and $\mathrm{pH}$ of the water remained constant at $26.8 \pm 0.09^{\circ} \mathrm{C}, 5.1 \pm 0.17 \mathrm{mg} / \mathrm{L}$ and $7.01 \pm 0.01$, respectively, which suggests that these parameters had no influence on the physiological parameters of the tambaqui specimens. The ammonia concentration in the tank water was $1.03 \pm 0.15 \mathrm{mg} / \mathrm{L}$ and was not considered toxic enough to change the physiological conditions of the fish (Cavero et al., 2004). The $\mathrm{pH}$ values, dissolved oxygen and water temperature were monitored daily using a Micronal B374 pH meter and an YSI 55/12 FT thermo-oximeter. The methods described by Verdouw et al. (1978) were used to determine the weekly amounts of ammonia. These values remained stable throughout the experimental period.

\subsection{Critical swimming speed}

The critical swimming speed (Ucrit) was determined by exposing the fish to a minimum acclimatization speed of $10 \mathrm{~cm} / \mathrm{s}$ for one hour and gradually increasing it by $10 \mathrm{~cm} / \mathrm{s}$ every 30 minutes until the fish became fatigued. The fish was considered to be fatigued when it failed to exhibit either natural or manually induced swimming stimuli. The Ucrit value was determined using the following formula, described by Brett (1964): Ucrit $=$ ui $+($ ti $/$ tiii $x$ uii), where ui = last swimming speed the fish achieved; $\mathrm{t} i=$ time at which the fish fatigued; tiii = stipulated time period for each speed; and uii $=$ speed at which the fish fatigued.

\subsection{Physiology parameters of tambaqui}

Erythrocyte values were determined by diluting the blood samples in formol-citrate solution at a proportion of 1:200 and counting cells in a Neubauer chamber. Hematocrit was measured using the microhematocrit method described by Goldenfarb et al. (1971), and the hemoglobin $(\mathrm{Hb})$ concentration was determined according to the cyanmethemoglobin method described by Van Kampen and Zijlstra (1961).

These results were used to calculate mean corpuscular volume (MCV), mean corpuscular hemoglobin $(\mathrm{MCH})$ and mean corpuscular hemoglobin concentration (MCHC), as described by Brow (1976).

The total protein and plasma triglyceride concentrations were determined using a colorimetric assay with a Doles commercial kit and readings in a Spectronic Genesis-2 spectrophotometer at 550 and $510 \mathrm{~nm}$, respectively. Glucose concentrations were determined using an Accu-Chek Advantage II electronic blood glucose meter, and cortisol concentrations were determined using a DRG Cortisol Enzyme Immunoassay kit (Germany) and reading in a plate spectrophotometer (Biotrak).

\subsection{Statistical analysis}

All data were expressed as the means and standard errors of the mean $( \pm$ SEM). After testing the normality of the data, the significance of differences was analyzed statistically using analysis of variance (one-way ANOVA) followed by the Tukey test for values that exhibited statistical significance. The level of significance was set at $\alpha=0.05$ for all analyses (Zar, 1984).

\section{Results and Discussion}

The tambaqui fed a diet supplemented with $30 \%$ camu camu showed significant increases $(\mathrm{p}<0.05)$ in mean weight and length on the 30th day of the experiment (Table 2). Moreover, in this same period, specimens fed with $15 \%$ fruit showed a significant increase $(p<0.05)$ in percentage weight gain, which did not occur with the other treatments during the study period (Figure 1).

Fish fed with different proportions of camu camu in this study showed greater variation in mean weight than growth (total length) at the end of the analyzed period, implying an increase in the muscle mass of these fish. These results may reflect the absorption of protein from the diet, but which is not used as energy for growth, as observed by Lovell (1989) and Aride et al. (2010).

Different species of fish have shown wide variations in their patterns of protein needed for good zootechnical performance. Lateolabrax japonicus exhibited weight gain increases with up to $41 \%$ protein in the diet (Ai et al., 2004), Ictalurus punctatus achieved maximum growth with $35 \%$ dietary protein (Li et al., 1998) and Oreochromis niloticus and $O$. mossambicus had the best net protein utilization and feed conversion results with crude protein levels of $30 \%$. According to Eckmann (1987), C. macropomum's best performance was achieved with $36 \%$ protein, corroborating the results of the present study, in which specimens showed significant growth and weight gain results with $36-37 \%$ protein in the diet over a period of 30 days. These variations may reflect the different requirements of the species under various forms of cultivation and dietary composition (Degani et al., 1989).

The high vitamin C content in camu camu is responsible for better dietary nutrient absorption, as its antioxidant 
Table 2. Mean ( \pm SEM) weight and height of tambaqui (C. macropomum) fed with feed supplemented with differing proportions of camu camu in the three analyzed periods.

\begin{tabular}{ccccc}
\hline \multirow{2}{*}{ Parameters } & \multirow{2}{*}{ Treatment } & \multicolumn{3}{c}{ Feeding period (days) } \\
\cline { 3 - 5 } & Control & $14.4 \pm 2.48$ & $15.9 \pm 3.59$ & $\mathbf{3 0}$ \\
\hline \multirow{3}{*}{ Weight $(\mathrm{g})$} & $15 \%$ & $13.2 \pm 1.17$ & $16.4 \pm 1.00$ & $23.6 \pm 2.41$ \\
& $30 \%$ & $13.2 \pm 1.16^{\mathrm{a}}$ & $13.3 \pm 1.46^{\mathrm{a}}$ & $22.8 \pm 2.46^{\mathrm{b}}$ \\
& $45 \%$ & $17.8 \pm 3.96$ & $16.0 \pm 3.27$ & $15.7 \pm 2.76$ \\
\hline \multirow{3}{*}{ Length $(\mathrm{cm})$} & Control & $7.47 \pm 0.55$ & $7.75 \pm 0.51$ & $8.27 \pm 0.31$ \\
& $15 \%$ & $7.32 \pm 0.19$ & $8.92 \pm 0.62$ & $8.47 \pm 0.40$ \\
& $30 \%$ & $7.37 \pm 0.25^{\mathrm{a}}$ & $7.60 \pm 0.28^{\mathrm{a}}$ & $8.83 \pm 0.30^{\mathrm{b}}$ \\
& $45 \%$ & $7.95 \pm 0.76$ & $7.72 \pm 0.49$ & $7.40 \pm 0.28$ \\
\hline
\end{tabular}

Different letters represent significant differences $(\mathrm{p}<0.05)$ of means $( \pm$ SEM $)$ between treatments in different feeding periods. SEM: standard errors means.

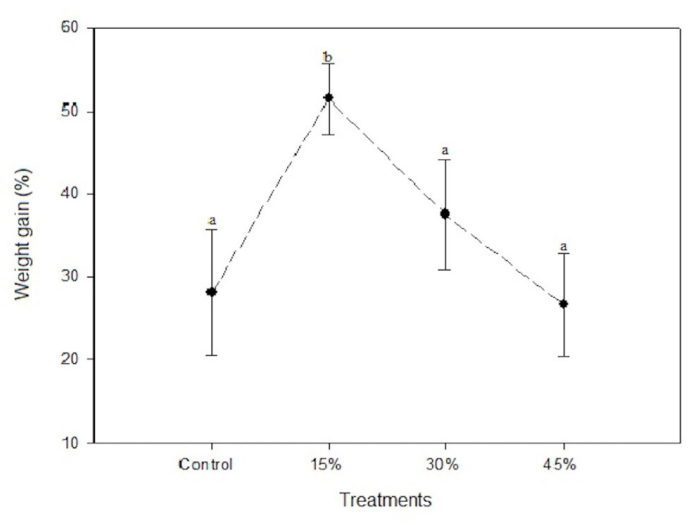

Figure 1. Mean values ( \pm SEM) of weight gain of C. macropomum fed rations supplemented with different camu camu proportions for 30 days. Different letters represent differences $(\mathrm{p}<0.05)$ between treatments. SEM: standard errors means.

properties prevent the actions of free radicals on lipids (energy reserve) and protein amino acids (Bianchi and Antunes, 1999; Aride et al., 2010), thus optimizing its uptake by the fish. In this study, the additions of $15 \%$ and $30 \%$ camu camu seem to have contributed to better dietary nutrient absorption, resulting in increased mean weight gain and growth, respectively. The results after increasing fruit content to $45 \%$ suggest a saturation of camu camu's intrinsic properties at this level, including the actions of possible antinutritional factors and the loss of essential nutrients from the material replaced by the fruit, causing reductions in body weight gain and growth. The primary evidence of protein deficiency is weight loss, which mainly occurs due to a lack of essential amino acids in the diet, preventing the formation of muscle tissue and other compounds important to the metabolism.

In this study, critical swimming speed (Ucrit) was used as a stressor and indicator of the tambaqui's nutritional and homeostatic status. The addition to the diet of $30 \%$ camu camu caused a significant increase $(p<0.05)$ in the critical swimming speed of fish in relation to the control diet. However, fish fed with $45 \%$ camu camu had a critical swimming speed similar to the control fish, which was significantly slower than that of fish fed with $30 \%$ camu camu (Figure 2).

The fact that the best swimming performance did not occur in the group with the highest weight gain (15\%) suggests that supplementation with $30 \%$ camu camu promotes an increase in the tambaqui's energy reserves, or that fish with lower body weight would have better swimming performance as long as they still have adequate energy reserves. The low swimming performance of fish fed with $45 \%$ camu camu suggests that this concentration does not provide the diet with the minimum amounts of protein and other minerals present in the commercial feed.

Hemoglobin and MCHC increased significantly $(p<0.05)$ in all groups of fish fed camu camu after 30 days of feeding, which did not occur with the controls. The other parameters did not change significantly during the study period (Table 3 ).

After the Ucrit, hematocrit increased significantly $(p<0.05)$ in all groups, indicating a mobilization of stocks of red blood cells released from the spleen by splenic contraction or a decrease in plasma volume (Randall, 1982; Franklin et al., 1993; Hackbarth, 2004). This increase confirms the results of Wilson and Egginton (1994) and Wang et al. (1994) when evaluating rainbow trout (Oncorhynchus mykiss) and tambaqui specimens fed fruit (embaúba, catoré and munguba) after intense exercise. The red blood count (RBC), $\mathrm{Hb}$ and $\mathrm{Ht}$ are considered the three hematological indices of the red series primary response, indicating the oxygen carrying capacity of the blood and its use by the organism (Hackbarth, 2004). The RBC and $\mathrm{Hb}$ levels in this study suggest a balance between supply and demand of oxygen of the organisms during aerobic exercise, increasing gas transfer due to better extraction and diffusion of oxygen among tissue, factors already observed by Randall (1982) and Jensen et al. (1983) in some species of tropical fish. The reduction of $\mathrm{MCHC}$ in fish fed with $15 \%$ and $30 \%$ camu camu $(\mathrm{p}<0.05)$ after the swimming test may be related to small increases in RBC and a significant increase in hematocrit during exercise. 
These results were observed during exhaustive exercise of O. mykiss (1994) and during sustained exercise of Brycon cephalus (Hackbarth, 2004).

The hematological parameters observed suggest good nutritional status among the fish fed camu camu

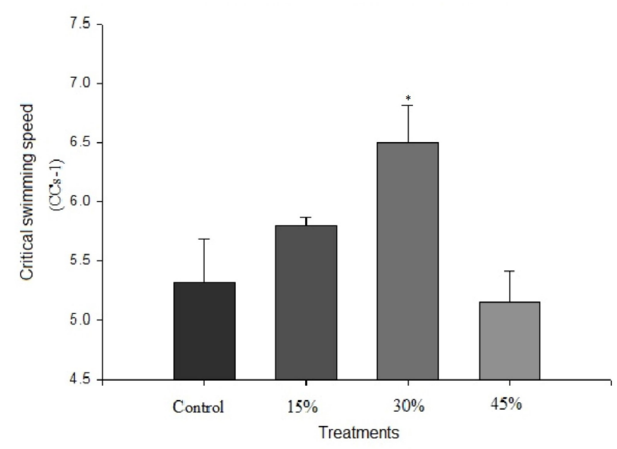

Figure 2. Mean ( \pm SEM) swimming performance of C. macropomum fed diets supplemented with different camu camu proportions. *indicates significant difference $(p<0.05)$ between treatments. SEM: standard errors means. and indicate adaptive processes that reduced the effects caused by stress. Tavares-Dias and Moraes (2004) note that, despite the lack of information and large variation between species, hematological parameters can be used to infer fish growth.

The total plasma protein and triglyceride values did not differ significantly among treatments in the analyzed feeding period. After Ucrit, there were significant increases in triglycerides in fish fed with $30 \%$ camu camu and in total proteins in fish fed $30 \%$ and $45 \%$ camu camu (Table 4 ).

The concentrations of these metabolites in the plasma may indicate a migration of extracellular fluids to the active muscles (Wang et al., 1994) or increased protein and lipid mobilization for intense muscle contraction (Van Den Thillart and Van Raaji, 1995). Davison (1997) demonstrates that fish with high swimming performance have increased lipid and protein deposits in the intestines and muscle, especially among salmonids, although other fish show reductions in these levels, revealing different energy patterns among species. The increases in plasma triglycerides and proteins only in the group fed $30 \%$ camu camu, i.e., the group with the fastest critical swimming

Table 3. Mean ( \pm SEM) number of erythrocytes (RBC), hematocrit (Ht), hemoglobin ( $\mathrm{Hb}), \mathrm{MCV}, \mathrm{MCH}$ and $\mathrm{CMCH}$ of C. macropomum specimens fed commercial feed supplemented with different proportions of camu camu.

\begin{tabular}{|c|c|c|c|c|c|}
\hline \multirow{2}{*}{ Parameters } & \multirow{2}{*}{ Treatment } & \multicolumn{3}{|c|}{ Feeding period (days) } & \multirow{2}{*}{ After Ucrit } \\
\hline & & $\mathbf{0}$ & 15 & 30 & \\
\hline \multirow{4}{*}{$\begin{array}{c}\mathrm{RBC} \\
\left(\mathrm{x} 10^{6} / \mathrm{mm}^{3}\right)\end{array}$} & Control & $1.23 \pm 0.16$ & $1.43 \pm 0.09$ & $1.63 \pm 0.20$ & $2.07 \pm 0.13$ \\
\hline & $15 \%$ & $1.28 \pm 0.09$ & $1.29 \pm 0.11$ & $1.48 \pm 0.07$ & $1.86 \pm 0.14$ \\
\hline & $30 \%$ & $1.20 \pm 0.10$ & $1.37 \pm 0.17$ & $1.71 \pm 0.14$ & $1.92 \pm 0.19$ \\
\hline & $45 \%$ & $1.18 \pm 0.15$ & $1.41 \pm 0.21$ & $1.60 \pm 0.19$ & $1.87 \pm 0.18$ \\
\hline \multirow{4}{*}{ Ht $(\%)$} & Control & $22.0 \pm 1.4$ & $26.2 \pm 1.4$ & $25.0 \pm 1.9$ & $33.0 \pm 2.0^{*}$ \\
\hline & $15 \%$ & $23.5 \pm 0.8$ & $25.2 \pm 1.7$ & $24.0 \pm 1.0$ & $32.5 \pm 1.1^{*}$ \\
\hline & $30 \%$ & $24.2 \pm 1.5$ & $24.7 \pm 0.9$ & $22.5 \pm 1.4$ & $32.0 \pm 0.9^{*}$ \\
\hline & $45 \%$ & $24.0 \pm 1.8$ & $26.6 \pm 0.8$ & $23.7 \pm 1.3$ & $30.5 \pm 1.0^{*}$ \\
\hline \multirow{4}{*}{$\mathrm{Hb}(\mathrm{g} / \mathrm{dL})$} & Control & $5.91 \pm 0.62$ & $6.66 \pm 0.58$ & $7.31 \pm 0.54$ & $7.93 \pm 0.39$ \\
\hline & $15 \%$ & $4.93 \pm 0.86^{\mathrm{a}}$ & $5.98 \pm 0.50^{\mathrm{ab}}$ & $7.46 \pm 0.43^{b}$ & $7.73 \pm 0.37$ \\
\hline & $30 \%$ & $6.15 \pm 0.78^{\mathrm{ab}}$ & $5.94 \pm 0.32^{\mathrm{a}}$ & $7.25 \pm 0.30^{\mathrm{b}}$ & $7.60 \pm 0.38$ \\
\hline & $45 \%$ & $5.70 \pm 0.61^{\mathrm{a}}$ & $5.89 \pm 0.11^{\mathrm{a}}$ & $7.16 \pm 0.27^{\mathrm{b}}$ & $8.53 \pm 0.54$ \\
\hline \multirow{4}{*}{$\operatorname{MCV}\left(\mu \mathrm{m}^{3}\right)$} & Control & $178.86 \pm 8.75$ & $183.22 \pm 15.5$ & $158.61 \pm 19.77$ & $162.20 \pm 19.35$ \\
\hline & $15 \%$ & $183.59 \pm 8.88$ & $195.35 \pm 4.54$ & $157.78 \pm 13.36$ & $175.90 \pm 8.21$ \\
\hline & $30 \%$ & $201.67 \pm 15.0$ & $180.29 \pm 18.82$ & $134.56 \pm 15.29$ & $173.07 \pm 23.53$ \\
\hline & $45 \%$ & $203.39 \pm 12.0$ & $188.65 \pm 5.24$ & $153.67 \pm 17.26$ & $167.87 \pm 19.49$ \\
\hline \multirow{4}{*}{ MCH (pg) } & Control & $48.05 \pm 3.87$ & $46.57 \pm 6.44$ & $45.80 \pm 3.31$ & $38.52 \pm 2.52$ \\
\hline & $15 \%$ & $38.52 \pm 9.55$ & $46.36 \pm 2.94$ & $50.67 \pm 4.82$ & $41.72 \pm 1.51$ \\
\hline & $30 \%$ & $51.25 \pm 7.8$ & $43.36 \pm 3.55$ & $43.28 \pm 3.84$ & $41.18 \pm 5.96$ \\
\hline & $45 \%$ & $48.31 \pm 4.1$ & $41.47 \pm 13.75$ & $46.41 \pm 4.87$ & $47.35 \pm 7.47$ \\
\hline \multirow{4}{*}{$\mathrm{CMCH}(\%)$} & Control & $26.68 \pm 1.71$ & $25.29 \pm 1.32$ & $29.45 \pm 1.71$ & $24.46 \pm 2.45$ \\
\hline & $15 \%$ & $20.72 \pm 3.13^{\mathrm{a}}$ & $23.67 \pm 0.78^{\mathrm{a}}$ & $29.43 \pm 0.87^{b}$ & $23.76 \pm 0.51 *$ \\
\hline & $30 \%$ & $25.07 \pm 1.72^{\mathrm{a}}$ & $24.06 \pm 1.23^{\mathrm{a}}$ & $32.75 \pm 3.05^{\mathrm{b}}$ & $23.70 \pm 0.54 *$ \\
\hline & $45 \%$ & $23.64 \pm 1.37^{\mathrm{a}}$ & $22.20 \pm 0.59^{\mathrm{a}}$ & $30.27 \pm 0.59^{\mathrm{b}}$ & $28.00 \pm 1.67$ \\
\hline
\end{tabular}

Different letters represent significant differences $(\mathrm{p}<0.05)$ of means \pm SEM between treatments in different feeding periods; *indicates significant difference $(\mathrm{p}<0.05)$ between specimens on the $30^{\text {th }}$ day of feeding and subjected to Ucrit. $(-)$ indicates non-evaluated parameters. 
speed, indicate that increasing the flow of these metabolites may contribute to better performance.

Glucose did not differ significantly $(p>0.05)$ among treatments when analyzed in the same feeding period. However, the control group and fish fed $30 \%$ and $45 \%$ camu camu showed significant increases $(\mathrm{p}<0.05)$ after 15 days of feeding, reaching intermediate values until the 30 th day of feeding. These results differ from those observed for Sparus aurata fed different levels of vitamin C $(25,50,100$ and $200 \mathrm{mg} / \mathrm{kg})$ (Henrique et al., 1998) and tambaqui fed 200 and $400 \mathrm{mg}$ ascorbic acid/kg feed and exposed to hypoxia (Chagas and Val, 2006), where the evaluated specimens showed no differences in plasma glucose values during the feeding period. Aride et al., (2006) also found no significant differences in tambaqui specimens subjected to different photoperiods. According to Pickering and Pottinger (1995) and Reid et al., (1998), various species of fish exhibit primary responses to stress, such as increased circulating catecholamines and corticosteroids, thus triggering secondary effects related to energy requirements, such as increased blood glucose by glycogenolysis and gluconeogenesis. These results were confirmed in our study, which showed significant increases $(p<0.05)$ in cortisol and glucose across all treatments (Figures 3 and 4) after the swimming stress test, indicating the natural responses of these metabolites in hyperglycemic production (energy mobilization). A similar pattern was observed in gilt-head bream (Sparus aurata) (Hyvarinen et al., 2004) subjected to swimming stress after being fed a diet with $100 \mathrm{mg}$ vitamin $\mathrm{C} / \mathrm{kg}$ and $100 \mathrm{mg}$ vitamin E/kg (Ortuño et al., 2003) and tambaqui fed different fruits and seeds native to the Amazon.

The present study demonstrates that camu camu is an efficient alternative in commercial diet supplementation, with $30 \%$ of the fruit providing the highest growth rate and best nutritional and homeostatic conditions. These results stimulate future studies to evaluated the alternative feed costs with camu-camu in the aquaculture in the Amazon Region. Larger proportions of camu camu seem to neglect potential nutrients in commercial feed, minimizing uptake by the fish, thereby reducing their nutritional levels and, consequently, their zootechnical and swimming performance levels. The different proportions of camu camu in the diet did not cause significant changes in hematological parameters, except after the physical stamina test. Plasma metabolic parameters showed biochemical adaptations for maintaining the energy uptake process during exercise. The Ucrit test was quite effective in inferring the actual nutritional status of the fish.

Table 4. Mean values \pm standard errors of total proteins and triglycerides in the plasma of C. macropomum fed diets supplemented with camu camu.

\begin{tabular}{cccccc}
\hline \multirow{2}{*}{ Parameter } & \multirow{2}{*}{ Control } & \multicolumn{2}{c}{ Proportion of camu camu in diet } \\
\cline { 3 - 5 } & & & $\mathbf{1 5 \%}$ & $\mathbf{3 0 \%}$ & $\mathbf{4 5 \%}$ \\
\hline Total proteins & without Ucrit & $2.73 \pm 0.07$ & $2.61 \pm 0.15$ & $2.49 \pm 0.18$ & $2.23 \pm 0.12$ \\
(g/dL) & with Ucrit & $3.17 \pm 0.278$ & $3.30 \pm 0.20$ & $4.15 \pm 0.25^{*}$ & $3.43 \pm 0.32^{*}$ \\
$\begin{array}{c}\text { Triglycerides } \\
\text { (mg/dL) }\end{array}$ & without Ucrit & $209.39 \pm 39.35$ & $196.61 \pm 70.44$ & $204.88 \pm 13.38$ & $245.86 \pm 15.42$ \\
\hline
\end{tabular}

*significant difference $(\mathrm{p}<0.05)$ for animals fed with the same diet, not subjected or subjected to the swimming stress test (Ucrit).

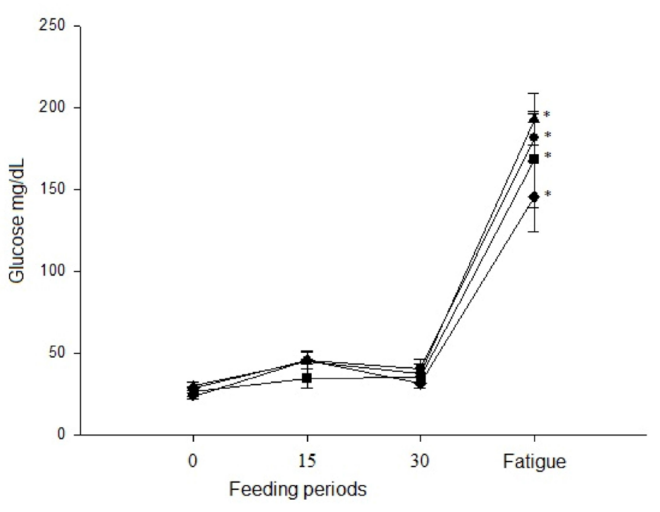

Figure 3. Mean ( \pm SEM) glucose values of C. macropomum fed diets supplemented with different camu camu concentrations. *indicates significant difference $(p<0.05)$ between treatments before and after swimming stress test (Ucrit). SEM: standard errors means.

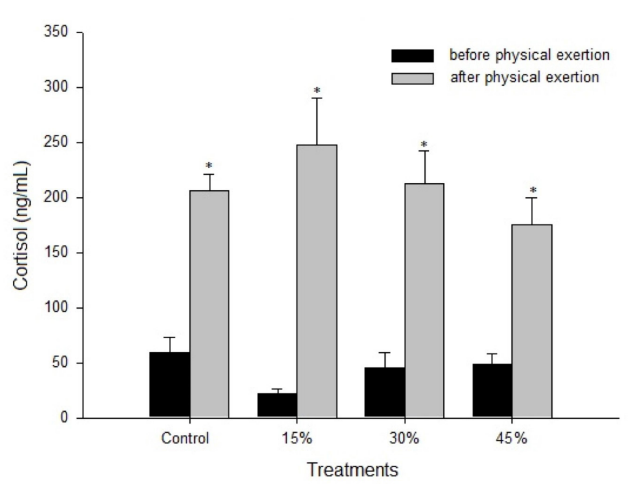

Figure 4. Mean ( \pm SEM) cortisol values of C. macropomum fed diets supplemented with different camu-camu proportions for 30 days and after being subjected to physical exertion test. *indicates significant difference $(p<0.05)$ between treatments before and after swimming stress test (Ucrit). SEM: standard errors means. 


\section{Acknowledgements}

The authors thank CNPQ (Conselho Nacional de Desenvolvimento Científico e Tecnológico) for providing grants (CNPq 557094/2005-4 and 554009/2006-4 ÔMEGA); the FAPEAM Foundation for the research fellowship to the last author and for providing grants to support this publication (Edital 020/2013-PAPAC); and the Post-Graduate Program in Aquaculture (PPG-Aquacultura-INPA - Nilton Lins) for the infrastructure. Thanks are also due to the anonymous reviewers for their truly helpful comments.

\section{References}

AI, Q., MAI, K., LI, H., ZHANG, C., ZHANG, L., DUAN, Q., TAN, B., XU, W., MA, H., ZHANG, W. and LIUFU, Z., 2004. Effects of dietary protein to energy ratios on growth and body composition of juvenile Japanese seabass, Lateolabrax japonicus. Aquaculture, vol. 230, no. 1-4, pp. 507-516. http:// dx.doi.org/10.1016/j.aquaculture.2003.09.040.

ARAÚJO-LIMA, C. and GOULDING, M., 1998. Os frutos do tambaqui: ecologia, conservação e cultivo na amazônia. Tefé: Sociedade Civil Mamirauá

ARIDE, P.H.R., FERREIRA, M.S., DUARTE, R.M., OLIVEIRA, A.M., FREITAS, D.V., SANTOS, A.L.W., NOZAWA, S.R. and VAL, A.L., 2010. Ascorbic acid (vitamin C) and iron concentration in Tambaqui, Colossoma macropomum, iron absorption. Journal of the World Aquaculture Society, vol. 41, pp. 291-297. http:// dx.doi.org/10.1111/j.1749-7345.2010.00370.x.

ARIDE, P.H.R., OLIVEIRA, A.T., OLIVEIRA, A.M., FERREIRA, M.S., BAPTISTA, R.B., SANTOS, S.M. and PANTOJA-LIMA, J., 2016 [viewed 17 September 2016]. Growth and hematological responses of tambaqui fed different amounts of cassava (Manihot esculenta). Arquivo Brasileiro de Medicina Veterinária e Zootecnia [online], vol. 68, no. 6, pp. 1697-1704. http://dx.doi. org/10.1590/1678-4162-8704. Available from: http://www.scielo.br/ scielo.php?script=sci_arttext\&pid=S0102-09352016000601697\&ln $\mathrm{g}=$ en\&nrm $=$ iso

ARIDE, P.H.R., ROUBACH, R. and VAL, A.L., 2007. Tolerance response of tambaqui Colossoma macropomum (CUVIER) to water pH. Aquaculture Research, vol. 38, no. 6, pp. 588-594. http://dx.doi.org/10.1111/j.1365-2109.2007.01693.x.

ARIDE, P.H.R., ROUBACH, R., NOZAWA, S.R. and VAL, A.L., 2006. Tambaqui growth and survival when exposed to different photoperiods. Acta Amazonica, vol. 36, no. 3, pp. 381-384. http:// dx.doi.org/10.1590/S0044-59672006000300015.

BIANCHI, M.L.P. and ANTUNES, L.M.G., 1999. Radicais livres e os principais antioxidantes da dieta. Revista de Nutrição, vol. 12 , no. 2 , pp. 123-130. http://dx.doi.org/10.1590/S141552731999000200001 .

BRETT, J.R., 1964. The respiratory metabolism and swimming performance of young sockeye salmon. Journal of the Fisheries Research Board of Canada, vol. 21, no. 5, pp. 1183-1226. http:// dx.doi.org/10.1139/f64-103.

BROW, B.A., 1976. Hematology: principles and procedures. 2nd ed. Philadelphia: Lea \& Febiger.

CAVERO, B.A.S., PEREIRA-FILHO, M., BORDINHON, A.M., FONSECA, F.A.L., ITUASSÚ, D.R., ROUBACH, R. and ONO, E.A., 2004. Tolerância de juvenis de pirarucu ao aumento da concentração de amônia em ambiente confinado. Pesquisa Agropecuária Brasileira, vol. 39, no. 5, pp. 513-516. http://dx.doi. org/10.1590/S0100-204X2004000500015.

CHAGAS EC and VAL AL. Ascorbic acid reduces the effects of hypoxia on the Amazon fish tambaqui. Journal of Fish Biology. 2006; 69(2):608-612. http://dx.doi.org/10.1111/j.10958649.2006.01094.x.

CHIRINOS, R., GALARZA, J., BETALLELUZ-PALLARDEL, I., PEDRESCHI, R. and CAMPOS, D., 2010. Antioxidant compounds and antioxidant capacity of Peruvian camu camu (Myrciaria dubia (H.B.K.) McVaugh) fruit at different maturity stages. Food Chemistry, vol. 120, no. 4, pp. 1019-1024. http:// dx.doi.org/10.1016/j.foodchem.2009.11.041.

DAVISON, W., 1997. The effects of exercise training on teleost fish, a review of recent literature. Comparative Biochemistry and Physiology Part A: Physiology, vol. 117, no. 1, pp. 67-75. http:// dx.doi.org/10.1016/S0300-9629(96)00284-8.

DEGANI, G., BEN-ZVI, Y. and LEVANON, D., 1989. The effect of different protein levels and temperature on feed utilization, growth and body composition of Clarias gariepinus (Burchell, 1822). Aquaculture, vol. 76, no. 3-4, pp. 293-301. http://dx.doi. org/10.1016/0044-8486(89)90082-3

ECKMANN, R., 1987. Growth and body composition of juvenile Colossoma macropomum Cuvier 1818 (Characoidei) feeding artificial diets. Aquaculture, vol. 64, no. 4, pp. 293-303. http:// dx.doi.org/10.1016/0044-8486(87)90192-X

FRACASSETTI, D., COSTA, C., MOULAY, L. and TOMÁSBARBERÁN, F.A., 2013. Ellagic acid derivatives, ellagitannins, proanthocyanidins and other phenolics, vitamin $\mathrm{C}$ and antioxidant capacity of two powder products from camu-camu fruit (Myrciaria dubia). Food Chemistry, vol. 139, no. 1-4, pp. 578-588. PMid:23561148. http://dx.doi.org/10.1016/j.foodchem.2013.01.121.

FRANKLIN, C.E., DAVISON, W. and MCKENZIE, J.C., 1993. The role of the spleen during exercise in the antartic teleost, Pagothenia borchgrevinki. The Journal of Experimental Biology, vol. 174, pp. 381-386.

FREEMAN, Z.J., 1995. Amazonian aquatic resources: fishery management and aquaculture development. Manaus: INPA/ FUA. Master's Thesis.

GOLDENFARB, P.B., BOWYER, F.P., HALL, E. and BROSIOUS, E., 1971. Reproducibility in the hematology laboratory: the microhematocrit determination. American Journal of Clinical Pathology, vol. 56, no. 1, pp. 35-39. PMid:5556212. http://dx.doi. org/10.1093/ajcp/56.1.35.

GOULDING, M., 1980. The fishes and the forest: explorations in Amazonian natural history. Berkeley, Los Angeles: University of California Press.

GRAEF, E.W., 1995. As espécies de peixe com potencial para criação no Amazonas. In: A.L. VAL and A. HONCZARIK, eds. Criando peixes na Amazônia. Manaus: Instituto Nacional de Pesquisas da Amazônia, pp. 29-43.

GRESSLER, E., PIZO, M.A. and MORELLATO, L.P.C., 2006. Polinização e dispersão de sementes em Myrtaceae do Brasil. Brazilian Journal of Botany, vol. 29, no. 4, pp. 509-530. http:// dx.doi.org/10.1590/S0100-84042006000400002.

HACKBARTH, A., 2004. Respostas metabólicas e de crescimento de matrinxãs (Brycon cephalus, Gunther, 1869) submetidos ao exercício sustentado. São Carlos: UFSCar. Dissertação de Mestrado. 
HENRIQUE, M.M.F., GOMES, E.F., GOUILLOU-COUSTANS, M.F., OLIVA-TELES, A. and DAVIES, S.J., 1998. Influence of supplementation of practical diets with vitamin $C$ on growth and response to hypoxic stress of seabream, Sparus aurata. Aquaculture, vol. 161, no. 1-4, pp. 415-426. http://dx.doi.org/10.1016/S00448486(97)00289-5.

HYVARINEN, P., HEINIMAA, S. and RITA, H., 2004. Effects of abrupt cold shock on stress responses and recovery in brown trout exhausted by swimming. Journal of Fish Biology, vol. 64, no. 4, pp. 1015-1026. http://dx.doi.org/10.1111/j.1095-8649.2004.0367.x.

JENSEN, F.B., NIKINMAA, M. and WEBER, R.E., 1983. Effects of exercise stress on acid-base balance and respiratory function in blood of the teleost Tinca tinca. Journal of Respiration Physiology, vol. 51, no. 3, pp. 291-301. PMid:6844761. http:// dx.doi.org/10.1016/0034-5687(83)90024-5.

LESLIE, T., 1998. Herbal secrets of the rainforest. Austin: Prima Publishing.

LI, M.H., ROBINSON, E.H. and WOLTERS, W.R., 1998. Evaluation of three strains of channel catfish Ictalurus punctatus fed diets containing three concentrations of protein and digestible energy. Journal of the World Aquaculture Society, vol. 29, no. 2, pp. 155-160. http://dx.doi.org/10.1111/j.1749-7345.1998.tb00974.x.

LOVELL, R.T., 1989. Nutrition and feeding of fish. New York: Van Nostrand Reinhold.

MELARD, C., OROZCO, J.J., URAN, L.A. and DUCARME, C., 1993. Comparative growth rate and production of Colossoma macropomum and Piaractus brachypomus (Colossoma bidens) in tanks and cages using intensive rearing conditions. In: G. BARNABE and P. KESTEMONT, eds. Production, environment and quality. Ghent: European Aquaculture Society, pp. 433-442.

MORAES, V.H.D., MULLER, C.H., DE SOUZA, A.G.C. and ANTONIO, I.C., 1994. Native fruit species of economic potential from the Brazilian Amazon. Journal of Applied Botany and Food Quality, vol. 68, pp. 47-52.

ORTUÑO, J., ESTEBAN, M.A. and MESEGUER, J., 2003. The effect of dietary intake of vitamins $\mathrm{C}$ and $\mathrm{E}$ on the stress response of gilthead seabream (Sparus aurata L.). Fish \& Shellfish Immunology, vol. 14, no. 2, pp. 145-156. PMid:12526878. http:// dx.doi.org/10.1006/fsim.2002.0428.

PICKERING, A.D. and POTTINGER, T.G., 1995. Biochemical effects of stress. In: P.W. HOCHACHKA and T.G. POTTINGER, eds. Biochemistry and Molecular Biology of Fishes. Amsterdam: Elsevier, vol. 5, pp. 349-379.

RANDALL, D., 1982. The control of respiration and circulating in fish during exercise and hipoxia. The Journal of Experimental Biology, vol. 100, pp. 275-288.

REID, S.G., BERNIER, N.J. and PERRY, S.F., 1998. The adrenergic stress response in fish: control of catecholamine storage and release. Comparative Biochemistry and Physiology
Part C: Pharmacology, Toxicology \& Endocrinology, vol. 120, no. 1, pp. 1-27. PMid:9827012. http://dx.doi.org/10.1016/S07428413(98)00037-1.

SAINT-PAUL, U., 1991. The potential for Colossoma culture in Latin America. Infofish International, vol. 2, pp. 49-53.

SOARES, M.G.M., ALEMIDA, R.G. and JUNK, W.J., 1986. The trophic status of the fish fauna in Lago Camaleão, a macrophyte dominated floodplain lake in the middle Amazon. Amazoniana, vol. ix, pp. 511-526.

TAVARES-DIAS, M. and MORAES, F.R., 2004. Hematologia de peixes teleósteos. Ribeirão Preto: Villimpress Complexo Gráfico. 144 p.

VAL, A.L., ROLIM, P.R. and RABELO, H., 2000. Situação atual da aqüicultura no norte. In: W.C. VALENTI, C.R. POLI, J.A. PEREIRA and J.R. BORGHETTI, eds. Aqüicultura no Brasil: bases para um desenvolvimento sustentável. Brasília: CNPq, Ministério da Ciência e Tecnologia, pp. 247-266.

VAN DEN THILLART, G. and VAN RAAJI, M., 1995. Endogenous fuels, non invasive versus invasive approaches. In: P.W. HOCHACHKA and P. MOMMSEN, eds. Metabolic Biochemistry. Amsterdam: Elsevier Science, vol. 4. pp. 33-63. Biochemistry and molecular biology of fishes.

VAN KAMPEN, E.J. and ZIJLSTRA, W.G., 1961. Standardization of hemoglobinometry. II. The hemiglobincyanide method. International Journal of Clinical Chemistry, vol. 6, no. 4, pp. 538-544. PMid:14453500. http://dx.doi.org/10.1016/00098981(61)90145-0.

VERDOUW, H., VAN ECHTELD, C.J.A. and DEKKERS, E.M.J., 1978. Ammonia determination based on indophenol formation with sodium salicylate. Water Research, vol. 12, no. 6, pp. 399402. http://dx.doi.org/10.1016/0043-1354(78)90107-0.

VILLACHICA, H.L., 1996. El cultivo del Camu Camu (Myrciaria dubia (H.B.K.) McVaugh) en la Amazonia Peruana: Tratado de Cooperación Amazónica (TCA). Lima: Secretaría Pro Tempore.

WANG, Y., HEIGENHAUSER, G.J. and WOOD, C.M., 1994. Integrated responses to exhaustive exercise and recovery in rainbow trout white muscle: acid-base, phosphogen, carbohydrate, lipid, ammonia, fluid volume and electrolyte metabolism. The Journal of Experimental Biology, vol. 195, pp. 227-258. PMid:7964413.

WILSON, R. and EGGINTON, S., 1994. Assessment of maximum sustainable swimming performance in rainbow trout (Oncorhynchus mykiss). The Journal of Experimental Biology, vol. 192, no. 1, pp. 299-305. PMid:9317845.

YUYAMA, K. and SIQUEIRA, J.A.S., 1999. Efeitos do tamanho da semente e do recipiente no crescimento de mudas de camu-camu (Myrciaria dubia). Acta Amazonica, vol. 29, no. 4, pp. 647-650. http://dx.doi.org/10.1590/1809-43921999294650.

ZAR, J.K., 1984. Biostatistical Analysis. 2nd ed. New Jersey: Prentice-Hall. 